Institut Agama Islam Negeri (IAIN) Curup, Indonesia
ISSN 2775-8621
volume 1, number 1, 2021

\title{
Chavismo and Venezuelan Foreign Policy Against the United States During 2013-2019
}

\author{
Hendra Maujana Saragih ${ }^{1}$, Muhammad Fikri Matdoan ${ }^{2}$ \\ Universitas Nasional, Jakarta, Indonesia \\ 1hendramaujana@gmail.com, 2muhammadfikri3@gmail.com
}

\begin{abstract}
This work desribe Chavismo as a populist movement and in making Venezuelan foreign policy directed towards the United States in the six years from 20132019. By using the Foreign Policy Theory which explains the function and purpose of foreign policy, it is found that Chavismo does not have much influence in making foreign policy towards the United States. The death of Hugo Chávez plus the poor economic conditions in the Maduro era, inevitably the problem of existence now plagues Chavismo. Chavismo under the government of Nicholás Maduro is in an alarming position. Where the position of this socialist movement no longer occupies a significant number as when Chávez, was still alive. The study of Chavismo in foreign policy is still possible given that Nicholás Maduro is a Chavista. Nicholás Maduro also carries out foreign policy with Chávez,s foreign policy. Sticking to the existing foreign policy, there is not much Maduro can do to maintain his power and the Bolivarian Revolution in Venezuela.
\end{abstract}

Keywords: Chávezism, Foreign Policy, Hugo Chávez, Nicholás Maduro, Bolivarian Revolution, and United State of America. 
NEGREI : Academic Journal of Law and Govenance,

Volume 1 Nomor 12021

\section{Introduction}

Venezuela has experienced an economic crisis over the past few years, precisely during the leadership of President Nicholás Maduro, which was marked by hyperinflation and shortages of food and medicine supplies. As a result, millions of Venezuelans have chosen to flee to neighboring countries to seek a better fate. The prolonged crisis experienced by Venezuela is a contrasting condition, considering that Venezuela is known as a petroleum-rich country. Economic conditions that are getting worse cannot be separated from the political chaos that makes the leaders of this country continue to be divided. Chavismo as an ideology maintained by Nicholás Maduro in carrying out his domestic and foreign policies has been accused of being one of the causes of the country's decline.

As a socialist doctrine, Chavismo must accept the onslaught of hegemony from the United States as a superpower with a liberal economy perspective, on the other hand Chavismo is slowly but surely being abandoned by his followers or known as Chavista because Nicholas Maduro as the leader of the country is unable to provide a decent life in the country. the US economic embargo. As a socialist doctrine, Chavismo will clearly continue to contradict the neoliberalism adopted by the United States, on the other hand, Maduro's failure to create economic stability has resulted in the loss of trust in Chavismo which was originally the energy for the Venezuelan people.

The phenomenon of the crisis that occurred in Venezuela is presenting the harsh reality that after all a small country will not be able to survive against the domination of the United States if it only relies on its natural resources. Because the domination of the United States is built on political forces that also come from its natural resources and the strength of its capital class. The main cause of the current Venezuelan crisis is the fall in oil prices due to the tightening of US oil spending, while the main consumer of Venezuelan oil is the United States. Venezuela's struggle for oil resources has proven to be of little long-term benefit.

\section{Problem Formulation}

According to research conducted by Jhon Magdaleno, the number of people who define themselves as Chavistas has decreased significantly from 44\% in October 2012 to 22\% in December 2014 (El-nacional.com,2019). As such this is a sign of the position of a Maduro in the Chavismo movement. So with these problems, a research question can be formulated in the form of: how did Chavismo influence 


\section{Hendra Maujana Saragih, Muhammad Fikri Matdoan \\ Chavismo and Venezuelan Foreign Policy \\ Against the United States During 2013-2019}

Venezuela's foreign policy towards the United States during the leadership of Nicholás Maduro?.

\section{Literature Review and Framework for Foreign Policy Theory}

As part of the international community, every country has national interests that they want to achieve, so they need cooperation with other countries. For this reason, every time in establishing relations with other countries an appropriate foreign policy and strategy is needed. According to Jackson and Sørensen (2014) foreign policy involves ideals, strategies, actions, methods, guidelines, directions, understandings, agreements, and so on, with which national governments engage in international relations and with international organizations and nongovernmental actors government. All national governments, by the fact of their separate international existence, are obliged to carry out foreign policies directed at foreign governments and other international actors. Governments want to influence the ideals and activities of other actors over which they have no complete control because they exist and operate outside their sovereignty (Carlsnaes 2002, 335)

Foreign policy consists of goals and actions intended to guide government decisions and actions regarding external affairs, especially relations with foreign countries. The management of foreign relations requires careful consideration of the action plans taken for the interests and foreign affairs of the government namely the goals of the government. Government officials in key positions - the president, prime minister, foreign minister, defense minister, finance minister and so on - along with their closest advisers - are usually key policy makers (Robert Jackson dan Georg Sørensen, 2014).

\section{Research Method}

In this study used a qualitative approach proposed by Bogdan and Taylor (1975) in Lexy J. Moleong, which defines a qualitative approach as a research procedure that produces descriptive data in the form of written or spoken words from people and observable behavior. According to them, this approach is directed at the individual's background holistically (whole). so in this case it is not permissible to isolate individuals or organizations into variables or hypotheses, but it is necessary to view them as part of a need (R Lexy J. Moleong, 2000). 
NEGREI : Academic Journal of Law and Govenance, Volume 1 Nomor 12021

The type or type of research used is a descriptive type of research. This type of research is based on "how" questions. Descriptive research provides a broader picture because this research is not only (with regard to) the problem itself, but also other variables related to the problem. And is more detailed because the variables are described on the factors (W.Gulö, 2005). The data used in this study were sourced from secondary data, the secondary data in the form of books, ebooks, e-journals, and articles contained in online media (online). while collecting data by using library research techniques, namely by looking for research data in public libraries that can be reached to provide the data needed in this study a number of books.

\section{Results and Discussion}

\section{1st Century Socialism Forms Resistance to Imprealism Socialism}

As terminology has many definitions. Therefore, socialism will be easier to identify through its characteristics. by Michael Newman (2006) who tries to draw the basic similarities that make up socialism with the following characteristics: "Socialism has the most fundamental characteristic, namely its commitment to the creation of an egalitarian society. Socialists may disagree about how far inequality will go or in what ways that change can be or in what ways it can be brought about, but no socialist advocates for the inequality in wealth and power that exists today. this. In particular, socialists are of the view that under capitalism, the ownership of capital and wealth has been hereditary to create enormous privileges and opportunities at one end of the pole and there is a cycle of poverty that limits opportunities and influence at the other end. another social pole."

Apart from that, Chávez actually stepped from the old socialism towards the socialism which he called "Twenty-first Century Socialism". This term first appeared and was used by Thomás Moulian, a Chilean sociologist, in 2000 in his bookentitled "Twenty-First Century Socialism: The Fifth Way", only when the Fourth Social Debt Summit on 25 February 2005 Chávez stated that "there is no alternative to capitalism other than socialism. but, (chaves also warns) this must be different from the socialisms we already know, we must create twenty-first century socialism." This twenty-first century (Marta Harnecker, 2015).

Socialism is also characterized by Hugo Chávez in three basic elements, namely: (1) economic transformation; (2) participatory and protagonist democracy in the political field; (3) and socialist ethics 'based on love, solidarity, and equality 


\section{Hendra Maujana Saragih, Muhammad Fikri Matdoan}

Chavismo and Venezuelan Foreign Policy

Against the United States During 2013-2019

between women and men, everyone', according to him, these socialist ideas and values are very old. This, according to Chávez, can be found in the scriptures, in the Bible, and in the practices of indigenous peoples (Marta Harnecker, 2015). The struggle to uphold socialism for Chávez must contain a number of core values that must not be ignored, by Magdoff and Foster (2018), Chávez is called promoting socialism which "raises social and environmental reasons to fight to abolish the oil rent model. Incredible considering that Venezuela is a major oil exporter" (Fred Magdoff dan John Bellamy Foster, 2018) and without neglecting environmental issues Chávez struggles to uphold what he believes in.

Socialism must be able to fight the forces of imperialism as well as capitalism, In this work, imperialism is more defined as the power of state capitalism as defined by James Petras and Henry Veltmayer, in the work of Empire With Imperialism, both of them designate the United States as an imperialist country whose power cannot be taken lightly. At the same time, he also called the era of globalization and global order as "21st century imperialism", in this work, imperialism is more defined as the power of state capitalism as defined by James Petras and Henry Veltmayer, in the work of Empire With Imperialism, both of them designate the United States as an imperialist country whose power cannot be taken lightly, At the same time, he also called the era of globalization and global order as "21st century imperialism" (Noam Chomsky, 2008) because according to Magdoff and Foster (2018) capitalism is considered to have its own character that can strengthen each other. And any new form of socialism or radical egalitarianism that seeks to overthrow it will only succeed if it can create alternative systems that are mutually reinforcing. President Hugo Chávez called these three basic sets of socialism: (1) social ownership of the means of production, (2) social production organized by the workers; and (3) fulfillment of communal needs (Fred Magdoff dan John Bellamy Foster, 2018). In this way, it is hoped that socialism will be able to subvert capitalism through programs that are far more focused on the public interest than the interests of the state.

\section{Hugo Chávez and Chavismo in Historical Way}

Venezuela has a populist movement based on local and international values that is revolutionary in nature, this movement was created by Hugo Chávez and is known as Chavismo, since Chávez took power in Venezuela in 1999. Along with the birth of the Chavismo movement and the Bolivarian Revolution created 
NEGREI : Academic Journal of Law and Govenance, Volume 1 Nomor 12021

political polarity between Venezuelan people. The two poles emerged as forces for and against the Revolution carried out by Chávez and Chavistas. It is also undeniable that what pushed Chávez to power for three terms in Venezuela, was a mass movement, a populist movement called Chavismo. Chavismo itself has various meanings, including as an ideology or as a populist movement, but in this paper we use both. By Kirk A. Hawkin, Chavimo is defined as: "Chavismo is a populist movement, and it has been since Chávez first came to prominence after the failed 1992 coop (Kirk A. Hawkins, 2010).

If defined as an ideology, Chavismo or Chavism or also Chávezism is Left-wing ideology originating from the ideas of Hugo Rafael Chávez Frias (Hereinafter referred to as Chávez) or better known as Hugo Chávez, former President of Venezuela from 1998-2013. In Chavismo itself there are elements of Socialism, Left-wing Populism, Patriotism, Internationalism, Bolivarianism, Feminism, Green Theory, and Integration of the Caribbean and Latin America. People who support Chavez and Chavismo are known as Chavistas.

Through the Bolivarian Revolution carried out by Chávez, his supporters were able to interact ideologically with various supporters of Bolivarian or socialist ideas that existed in other countries. This interaction is the key to the strong resistance between Chavismo and the United States. The foundation of the resistance, of course, comes from the anti-imperialist attitude shown by the Venezuelan people (Maduro is a Chavistas because his appointment by Chávez and his victory in the election for two consecutive terms as president of Venezuela is proof that a Maduro is a Chavistas). There are several indicators to be able to observe Chavismo as part of foreign policy, namely a foreign policy that is socialist, regionalist and leans towards anti-imperilism forces. Where Chávez used to try to build regional power socialist through ALBA, the South Bank. Telesur, UNASUR, UNASUR means the United Nations of South America, which was initiated at the 2006 Meeting of the South American Nations in Bolivia, previously preceded by the First South American Summit held in Brazil in 2000, then in Ecuador in 2002 and Peru in in 2004, in 2005 Brazil hosted the Association of South American Nations. Back at the Association of South American Nations Meeting in Bolivia in 2006, at which time the foundations for the United Nations of South America were laid, the mention of UNASUR only occurred at the Energy Summit in Venezuela in 2007, and as an organization the treaty was ratified in Brazil in 2008. (Edited from Marta, 2015). UNASUR, are 


\section{Hendra Maujana Saragih, Muhammad Fikri Matdoan}

Chavismo and Venezuelan Foreign Policy

Against the United States During 2013-2019

pro-Palestinian independence, and build cooperation with China, Russia, and Cuba. However, in the realm of Chavismo's audience, which in this case is represented by the poor who are pro to Chávez or the Chavistas, they are more focused on domestic policies.

However, during Chávez's tenure he always acted as the main actor carrying out diplomatic functions for Venezuela. Therefore, the function of the foreign ministry becomes less visible. Even though at that time Maduro was in charge of the foreign ministry, Chávez and the Ministry of Energy, which oversees the state oil company, PDVSA, still dominated the policy. Even the opposition and other policy makers did not get much of a role. Eva Golingger stated that the making of the Law on International Funding for Non-Governmental Organizations or NGOs did not really involve proposals from the people. The United Socialist Party of Venezuela (PSUV) also frequently provides comments on foreign relations issues, but its role in foreign policy is very limited. This era of foreign policy is so ideosyncratic.

This pattern of patron-like policy will certainly have a very institutional impact on the Ministry of Foreign Affairs. And it was evident when Chávez died that institutional work became less effective. The Ministry of Foreign Affairs lost its grip in carrying out its diplomacy because it had been "entrusted" to Chávez. The Venezuelan public does not fully believe in Chavistas' foreign policy. However, foreign policy becomes less meaningful when faced with domestic issues now plaguing Venezuela (Jean-Paul Marthoz) Therefore, Jean-Paul Marthoz claimed that Chavistas had carried out an aggressive "anti-imperialist" policy at home, with the intention of uniting the coalition groups and condemning the opposition's attitude by labeling them as unpatriotic parties for defending foreign interests (Jean-Paul Marthoz).

\section{Bolivarian Revolution Attempts to Make Venezuela the Epistrum of the New World Political Map}

The Bolivarian Revolution is always associated with the big name Hugo Chávez, because Chávez is considered the person who sparked the ideas of the revolution. The Bolivarian Revolution of course stands on the basis of the Bolivarian Constitution or the 1999 Constitution, this constitution replaces the position of the 1961(Nurani Soyomukti, 2007). Constitution, after the amendments made to 
NEGREI : Academic Journal of Law and Govenance, Volume 1 Nomor 12021

the government of Hugo Chávez. In fact, this amendment to the constitution began with a referendum to determine whether amendments were needed or not, the majority of the people voted for the amendment. This constitution is the first constitution to go through a referendum so that it is more democratic. This constitution brought significant changes to the Bolivarian Revolution. Through an article entitled "Venezuela: The Political Evolution of Bolivarianism", Julia Buxton tries to introduce the evolutionary process of Bolivarianism that developed in

Venezuela until 2010. This assumption comes from Julia Buxton, in fact Boliavarianism and Chavismo have different scopes, in the work of Conscience Soyomukti, it can be assumed that Bolivarianism is a medium or space for the Chavismo movement and the left movement in Venezuela. because Bolivarianism developed from the 1999 Bolivarian Constitution drawn up by Chávez with the support of the Venezuelan people. While Chavismo is an understanding or ideology that has developed through the actions and mindset of Hugo Chávez Frias since his involvement in the 1992 coup, Chavistas is one of the actors in the Bolivaraian Revolution.

Buxton views that the Venezuelan Bolivarian Revolution is seen by supporters and critics alike as an example of a paradigmatic shift in contemporary Latin American politics to the left. The Bolivarian Revolution seeks to make Venezuela the epicenter of the new world political map. The election of Chávez as president of Venezuela was the beginning of the rise of leftist forces in the twenty-first century in Latin America- fears of a domino effect and a regional left-wing contagion really happened later, This wave of leftist revival really happened when Luis Inácio Lula Da Silva was elected president of Brazil and Ricardo Lagos was elected president of Chile in 2002, then Néstor Kirchner as president of Argentina in 2003, and Tabaré Vázques won in Uruguay in 2005, in 2006 Michelle Bachelet won in Chile, Evo Morales in Bolivia, Rafael Correa in Ecuador and Daniel Ortega in Nicaragua. In 2008 Cristina Fernándes won in Argentina and lvaro Colom won in Guatemala, in 2008 Fernando Lugo won in Paraguay, and in 2009 Mauricio Funes in Uruguay, and Evo Morales was re-elected in Bolivia (Marta Harnecker, 2015). Entering the twenty-first century it was Latin America which had always been proud as the dominant region of Venezuela. Right-wing powers at that time switched because of great disappointment with Neoliberal practices that had failed to prosper the people of Latin America. 


\section{Hendra Maujana Saragih, Muhammad Fikri Matdoan}

Chavismo and Venezuelan Foreign Policy

Against the United States During 2013-2019

Chávez's presence with the Bolivarian Revolution or his bolivarianism for Julia Buxton for a decade (1999-2009) Bolivarianism (which she equates with Chavismo), This assumption comes from Julia Buxton, in fact Boliavarianism and Chavismo have different scopes, in the work of Conscience Soyomukti, it can be assumed that Bolivarianism is a medium or space for the Chavismo movement and the left movement in Venezuela. because Bolivarianism developed from the 1999 Bolivarian Constitution drawn up by Chávez with the support of the Venezuelan people. While Chavismo is an understanding or ideology that develops through Hugo's actions and thoughts. Has "produced a truly transformative project in Venezuela," but in a later sentence he criticizes it as "a truly transformative project in Venezuela." whose sustainability and capacity for institutionalization is in question." But Buxton also praised that the Bolivarian Revolution had a positive effect on a significant shift in economic and political power from the elite in Venezuela to the majority who were previously excluded and economically marginalized. As Buxton, according to Magdoff and Foster (2018), there have been progressive steps taken by the Bolivarian Revolution, they very clearly state that (Fred Magdoff dan John Bellamy Foster, 2018) :

"In Venezuela, the government has been able to carry out plans in several areas to improve social and environmental conditions for some citizens, the Venezuelan Bolivarian Revolution has prompted a radical shift to selfgovernment regulation, decentralized decision-making on basic community infrastructure and the provision of social services to tens of thousands of community councils. . With this people can participate in meeting the needs of the community."

In addition, Buxton sees that the narrative of Bolivarianism gives a new form to the pattern of relations between the north and the south which used to be patronclient, where the north has always been the parties served by countries in the south of the Americas. The Bolivarian Revolution then sought to change this with a more egalitarian regional union between the north and south. Hence for Buxton the main aim of the Bolivarian Revolution was to gradually seek to create twenty-first century socialism. In order to get to that stage Julia Buxton divided the Bolivarian Revolution into three phases, the first phase, namely constitutionalism and moderation, which has five main agendas (1) trying to make Venezuela a counterweight to the domination of the United States, without 
NEGREI : Academic Journal of Law and Govenance,

Volume 1 Nomor 12021

expressing direct hostility to neoliberalism and anti-Americanism; (2) replacing the oligarchic political system, namely punto fijo; (3) creating protagonist democracy; (4) create a productive economy in Venezuela; (5) and build national Integrity. The second phase of the Bolivarian Revolution stage is called the conflict and radicalization phase, in this stage Chávez and his defenders have been bolder in expressing their resistance (conflict) against the United States and Neoliberalism, by expanding Bolivarian thought and increasing popular programs (radicalization).

To oppose Chávez the opposition forces then used tactical steps through coups (2002) and referendums (2004). In her writings, Julia Buxton, builds on two main arguments about the Bolivarian Revolution. First, the Bolivarian Revolution aims to create twenty-first century socialism to replace various socialist revolutions that she considers to have failed. Although in the meaning of socialism it does not have a clear definition and is often contested, it does not mean that its creation cannot be realized for a society. To reach the level of socialism in the twenty-first century, three separate stages are needed, namely, building a social democratic climate; the formation of a more radical left; and created the twentyfirst century model of socialism. And Buxton felt that these three stages were strongly influenced by external factors in the form of a hostile reaction between the Bolivarian Revolution and the United States, the increase in world oil prices, and the shift in American politics to the left.

The second argument is that the Bolivarian Revolution is a unique phenomenon in Venezuela and is not related to other countries or influences other countries. Buxton argues that "because the state (which) determines the variables that support Boliavarianism (identified as the influence of the pre-Chávez political legacy and the dominance of the oil economy), the revolution cannot be replicated or transferred to the context of other countries" with the fight against Punto Fijo. In contrast to Buxton, Conscience Suyokmukti (2007) actually considers that the Bolivarian Revolution has been able to move the Venezuelan people to organize and care about every existing political, economic and social process. In the end the people formed the Bolivarian Circle on December 17, 2001, this people's movement has a network to overseas, with an estimated 1,500,000 members and 10 percent of them are Venezuelans. In 2003 the number of members increased to 2.2 million people. Networks of Bolivarian circles have even existed in Brazil, Chile, Argentina, Nicaragua, El Salvador (Nurani 


\section{Hendra Maujana Saragih, Muhammad Fikri Matdoan}

Chavismo and Venezuelan Foreign Policy

Against the United States During 2013-2019

Suyomukti 2007). Differently if you follow Buxton's definition of Bolivarianism, it is clear that Chavismo is not a special stand-alone phenomenon as he stated, because according to Hawkins (2010) Chavismo has links with various populist movements led by Evo Morales in Bolivia, namely Movimiento Al Socialism In Bolivia and Rafael Correa with the PAIS Alliance in Ecuador (Kirk A. Hawkins, 2010).

But the struggles of Chávez and the Bolivarian Revolution and Chavismo he left behind are a long-term solution. Because Chavismolah is now one of the spirits in the steadfast Bolivarian Revolution in Venezuela to fight US imperialism. For this reason, as long as Maduro is steadfast in sticking to the principles of the Chavimo struggle that he embraced from a young age, he will be able to defend the Bolivarian Revolution and the ideals of socialism that Chávez hopes for Venezuela. Chavismo's struggle must be strengthened from its roots with programs that not only target the poor but have a large and manageable return effect for the prosperity of Venezuela again.

\section{Chavismo in the Leadership of Nicholas Maduro}

As the successor to the late Chávez Maduro, he has a moral responsibility as Chavistas to defend everything and all the achievements that have been made by the late Chávez. The same concern also occurred as in Yugoslavia, under the rule of Josip Broz Tito who was able to unite various ethnic groups. But after his death the country fell apart and was mired in civil war (Majalah Tempo, 2019). The inheritance that Hugo Chávez had given him. However, groups against Chavismo always say different things about Chavismo. So Luis Vicente Leon, director of the political consultancy Data analysis, states that "there is no more Chavismo without Chávez, just like there is no platform without platform or sandism sonder sandino

Unfortunately he did not realize that the main engine for driving Chavismo's ideas was not Hugo Chávez, but Adan Chávez Frias, the older brother of Hugo Chávez, Alberto Garindo, as a biographer of Hugo Chávez, mentioned who and what important role an Adan Chávez played, namely "an ultra left who had been involved in the revolutionary guerrilla movement long before Chávez, Adan is a professor of political science at the University of the Andes. Adan was appointed Venezuelan ambassador to Cuba, also served as minister of education, and 
NEGREI : Academic Journal of Law and Govenance,

Volume 1 Nomor 12021

governor of barinas, until he became leader of Hugo Chávez's successful team in his last election. As reported by el Nuevo, Adan made his home the "kitchen of the Chavismo movement", where many activities were carried out ranging from politics, art, to education (Majalah Tempo, 2019). He was a man who was more principled than Chávez. Actually he is the fire of Chavismo's spirit all this time" It was Adan who gave the idea of dividing houses for the poor, which resulted in Chávez's increasing popularity.

However, there are still those who insist that Chavismo has died under Maduro's leadership, as stated by Roland Denis in his article republished by Venezuelan Analysis. With the provocative title of "Goodbye to Chavismo" or "Goodbye to Chavismo", Roland assumes that as a movement Chavismo has failed to transform in the bureaucratic structure during Chávez's leadership. Roland's provocative writings have received many responses, one of which is from Luigino Bracci, who wrote a rebuttal that Chavismo had played a role in inspiring many poor Venezuelans to realize how depraved it was during the Fourth Republic when the oligarchy was in power (Majalah Tempo, 2019).

All the criticisms directed by Roland do not mean that he is antipathetic to the struggles carried out by Chávez but on the contrary, he feels that Chavismo needs to be fought and even needs to be continuously purified from the abuses carried out by corrupt and irresponsible elites. Because the implementation of Chavismo by the elite and the audience is sometimes so different, a clash between reality and ideality.

\section{Foreign Policy of Nicholas Maduro}

Nicholás Maros Maduro is the Venezuelan president who has been in power since winning the elections in 2013. He is a confidant of Chávez, because before Chávez died he appointed Maduro as acting president. Like Chávez, Maduro also experienced a coup. The coup was carried out by Maduro's opposition, namely Juan Guaido, who at the time headed Venezuela's National Assembly or Parliament. On January 23, 2019 Juan Guaido unilaterally declared himself interim president of Venezuela, source from official website of the United States government, Maduro is no longer referred to as president (State.gov, 2019). After the unilateral statement, the United States immediately responded to Guaido's claim by giving approval to Guaido's leadership, In the official website of the United States government, Maduro is no longer referred to as president. See 


\section{Hendra Maujana Saragih, Muhammad Fikri Matdoan}

Chavismo and Venezuelan Foreign Policy

Against the United States During 2013-2019

State.gov, Recognition of Juan Guaido as Venezuela's Interim President United States Department of State (State.gov, 2019). This has finally strengthened the Venezuelan public's confidence in the indirect involvement of the United States in the effort to overthrow Maduro as well as a way to hinder the Bolivarian Revolution that is currently taking place in Venezuela. Unfortunately, the coup carried out by Guaido received considerable support from many leaders of countries and international organizations such as the United States, the European Union and NATO. The United States actually considers that the election of Juan Guaido as president is a democratic step because the National Assembly is democratically elected (State.gov, 2019).

Earlier on Sunday, August 6,2017, there was an attack on a military base in the city of Valencia by twenty people in military uniform. As reported by Al Jazeera, the Venezuelan government sent troops and quelled the military action within four hours. Two people are reported to have died. On national television, President Maduro called the group "terrorists" paid for by leaders of the antigovernment movement based in Miami and Colombia. The attack was aimed at seizing weapons and provoking rebellions in other military bases. "This is not a coup," Caguaripano said in a video released while occupying Fort Paramacay, a military base in Valencia. "This is an act of citizens and the military to re-establish the constitutional order. More than that, to save the country from total destruction (Windu Jusuf, Tirto.id).

Captain Juan Caguaripano Scott was a soldier with the rank of captain. In 2014, the government issued a warrant for Caguaripano's arrest for an alleged attempted coup. In the video, Caguaripano calls for the formation of a transitional government and will attack military units that are not aligned with his movement. The Los Angeles Times reported that the action came a day after the Constituent Assembly decided to hold its inaugural meeting to draft a new constitution. Maduro's critics argue that the establishment of a Constituent Assembly is aimed at removing the opposition that controls parliament. The proliberal democracy narrative stated by Guaido became his capital to gain support from various countries. But the United States' intervention in Venezuela's domestic politics has shown a very strong imperialist character and is contradictory or paradoxical to the democratic nature and the defense of human dignity that is often voiced. 
NEGREI : Academic Journal of Law and Govenance,

Volume 1 Nomor 12021

Maduro and his loyalists have not remained silent in the face of this coup, People who support Maduro are Cilia Flores (wife of Nicholás Maduro, first lady of Venezuela), Tarek William Saab, Delcy Rodríguez (vice president of Nicholás Maduro), Jorge Rodríguez (Former Vice President of the era of Hugo Chávez), Hector Rodríguez (governor of Miranda), Rafael Lavaca (Governor of Carabobo), Tareck El Aissami (Minister of Industry and National Production, Former Vice President Maduro), Diosdado Cabello (Minister of the Armed Forces), Vladimir Padrino Lopez (Minister of Defense), Maikel Moreno (Chairman of Justice). While the people who supported Juan Guaido were, Carlos Vecchio (United States Ambassador to Venezuela), Gustavo Tarre (OAS Ambassador), Leopoldo Lopez (Commissioner General for the Provisional Government), Julio Borges (President for the Foreign Relations Commission), Hendry Ramos Allup (Actión Democrática, AD), Stalin Gonzáles (Un Nuevo Tiempo) (Moises Rendon and Mark L. Schneider). They are trying to fight both Juan Guaido and the United States. Even the coup carried out by the National Guard Forces was successfully thwarted by Maduro's Security Forces (Kompas TV, 2019). Maduro has also accused the United States, Colombia and Chile of masterminding the coup and is seeking to replace Maduro with a general or former minister. Maduro is unmitigated to think that the party that carried out the coup against him was a fascist group, According to CNN's Jorge Rodriguez, Venezuela's communications minister, the coup was carried out by several active and retired military officers. The coup was led by General Antonio Rivera but the masterminds of the coup were Juan Guaido, Colombian president Ivan Duque, Chilean president Sebastian Pinera, and US presidential security adviser John Bolton. According to the confession of the officer who was detained by Maduro, lieutenant Carlos Savedra, who is the nephew of Ramon Cavedra, they wanted to kill Maduro and replace him with former defense minister Raul Baduel, who was Minister of Defense since the late Hugo Chávez cabinet. But he was sacked by Maduro because of his involvement in this coup. The coup targeted three military bases and the Lacarlota airport in the capital Caracas (CNN Indonesia, 2020). As a result of this coup, Venezuela was dragged into a political crisis because of the division of executive power. Maduro and Guaido are always trying to negotiate. However, if you look at the map, Juan Guaido's foreign political power is much stronger because it has been supported by 50 countries. Meanwhile, Maduro only gets support from Russia, China, Turkey, North Korea and Cuba. 


\section{Hendra Maujana Saragih, Muhammad Fikri Matdoan}

Chavismo and Venezuelan Foreign Policy

Against the United States During 2013-2019

When compared to the coup that was experienced by Hugo Chávez in 2002, Maduro seems to have experienced a declination in terms of the support given to him by Chavistas. Chávez's coup, which was masterminded by businessmen, one of whom was gathered in Facedemaras, did not run smoothly and only lasted 48 hours because of the coup Chávez. The Venezuelan public has taken to mass action to demand that Chávez be reinstated as president. In addition, the military was also more inclined to the Bolivarian Revolution offered by Chávez, thus preferring to fight against those who did. What happened to Maduro actually showed a decline in support. Because Maduro is supported by the forces that exist in the political structure (such as the military) than Chávez who gets support from the Venezuelan public directly. The tough and long time for Maduro to completely restore his legitimacy in international politics as the only president of Venezuela after the coup, this seems to imply that Chavistas does not play a significant role in strengthening Maduro's position in the international world.

Countless the death threats that Maduro has always received have intensified, including as reported by $\mathrm{CNN}$, which said that there had been an attempted assassination using an unmanned drone when Maduro gave a speech at a military celebration in the capital, Caracas, on August 4, 2018. At that time two drones containing dangerous explosives were detonated near Maduro. According to analysts' analysis, Maduro's opposition is just waiting for the right time to change Venezuela's political system to suit the will of the United States, if Maduro is later killed in an assassination plot. And in the history of Latin American politics this has happened very often. The same tragic fate was also experienced by Evo Morales, the former president of Bolivia who had to flee to Mexico (Ardi Priyatno Utomo, Kompas.co, 2019) due to being forced to resign, because his power had been "taken away" by the military through a request to resign, Although Morales declared himself resigning but Maduro called it a coup, former Brazilian President Luiz Inaciao Lula da Silva also supported Morales, saying the Bolivian president was "forced to submit" to resign (www.merdeka.com, 2019). The weakening of Morales will of course have an impact on the path of socialism that Venezuela is taking. With fewer countries allied with Venezuela, of course Venezuela will lack options for regional cooperation.

The threat faced by Maduro is also much greater because he is not someone who has the leadership qualities of Chávez. Chávez built his political career since 
NEGREI : Academic Journal of Law and Govenance, Volume 1 Nomor 12021

becoming a soldier and his popularity increased when he failed to seize power through a coup from Carlos Andrés Pérez in 1992. His charisma as a leader was even able to mobilize most of the Venezuelan people to get involved in changing the Venezuelan constitution, and carrying out the Bolivarian revolution. This is in stark contrast to Maduro, who built his political career through civilian leadership and lacked charisma. Maduro is also considered by many observers to be only carrying out the foreign policy he has inherited from Chávez. Chavismo under the government of Nicholás Maduro is in an alarming position. Where the position of this socialist movement no longer occupies a significant number as when Chávez was still alive. After the death of Hugo Chávez plus the poor economic conditions in the Maduro era, the issue of existence now plagues Chavismo.

Maduro remains in conflict with America United States because America is considered the mastermind of the crisis experienced by Venezuela. Maduro is also involved in building regional powers such as ALBA and the OAS. Even though Maduro is more focused on ALBA. The best cooperation between Venezuela and Cuba has also been strengthened, and the United States has even imposed sanctions on both of them. As well as increasing trade relations with China and Russia. During his reign, Maduro has also not been able to produce a more stable source of funding for Venezuela than oil. So that the strengthening of the PetroCaribe program continues. The United States is not a country that has seriously implemented democracy until now because it is more involved in efforts to undermine the democratic power that exists in a country, such as Venezuela.

The democratically elected Maduro is plagued by the presence of Guiado and military groups that serve the United States and its interests. Even though all of Maduro's good achievements in leading Venezuela have also been carried out, for example through the Barrio Adentro program, a health mission that serves the poor Venezuelan people. but the opposition and the US media have consistently positioned Maduro as an opponent of democracy and a threat to civil liberties. In a chaotic situation, Juan Guaido, after declaring himself interim president of Venezuela, was immediately greeted with the lure of pouring aid funds from the United States. In such a desperate situation, Maduro is at a disadvantage. Meanwhile, Chvasitas, who actually comes from the lower middle class, will be even more miserable. Maduro may still be able to live well as a President but what 


\section{Hendra Maujana Saragih, Muhammad Fikri Matdoan}

Chavismo and Venezuelan Foreign Policy

Against the United States During 2013-2019

about Chavistas? Given that if an economic crisis occurs, this will be more pronounced among the poor, it will be very difficult for the Chavistas to survive and continue to support Maduro and the Bolivarian Revolution.

It did not stop there, Juan Guaido also accused Maduro of cheating in the elections held in May 2018. Allegations of this kind often appear even since Chávez first came to power. The opposition's failure to gain votes to overwhelm the represented socialist axis (PSUV) has never been successful. In fact, this has happened in presidential elections over the past two decades. by looking at the vote that is quite significant for Maduro it is clear that Maduro is still in power today because of Chavismo's strength that supports him. Without Chavismo of course it will be very difficult for Maduro to win. Without Chavismo who fights against the hegemony of the United States through his media, which often corners the strength of the Bolivarian Revolution and its socialist ideas, how could Maduro have survived to this day. Not only accusations of electoral fraud, the opposition even accused the Maduro government of corruption, based on data released by the Americas Society/Council of the Americas (AS/COA) and Capacity to Combat Corruption (CCC), or the ability to fight corruption, Venezuela's CCC points are low at 1.71 when compared to countries in Latin America, the assessment is based on the state's ability to prevent, take action, and punish the perpetrators of corruption. (www.americasquarterly.org)

The United States also took a counter-step by freezing Venezuela's assets in its country (www.wartaekonomi.co.id, 2019). This is opposed by the United Nations because it could exacerbate the crisis in Venezuela. Chile's former president, Michelle Bachelet, even said that the sanctions would affect the most vulnerable sections of society (www.okezone.com, 2019). But there are similarities in the underlying narrative or reasons for the two camps in the struggle for power in Venezuela. Both camps claim that his actions were inspired by Simon Bolivar. And these narratives of Simón Bolivar's heroism overlap with one another. But Guaidó's camp was completely oblivious to the fact that Simon was a symbol of resistance to imperialism, which at that time was represented by Spain. This is evidenced by the liberation movement that was echoed by Simon, one of which was inspired by the independence movement in the United States (1776) and the French Revolution (1789). These two historical moments motivated Simon to liberate Latin America from Spanish colonization. By 
NEGREI : Academic Journal of Law and Govenance,

Volume 1 Nomor 12021

bringing the narrative of Simon or Boliavarianism, Guiado should have realized that the main actor of $i \backslash$ mperialism in this century is the United States.

Mijares stated that foreign policy in the Maduro era focused on efforts to change the outlook on Venezuela's foreign policy from the past. In the past foreign policy sought to seek international influence or support for Venezuela. However, during Maduro's time, the orientation of foreign policy changed to a policy that reacted to international conditions. It is very clear that Maduro is more focused on carrying out domestic policies in order to consolidate the political forces that have disintegrated since Chávez's death. The shifting political map caused the opposition groups to benefit because Chavismo lost his patron. Compared to Chávez's time, now the option group has become a more threatening force than ever before. Maduro's own foreign policy is referred to as the Maduro Doctrine by Víctor M. Mijares, in Venezuela's Post Chávez Foreign Policy (Víctor M. Mijares, 2015).

Victor Mijares even criticized Maduro's foreign policy pattern by calling it a foreign policy that shifted from "an aggressive revolutionary internationalization process to a less smooth model of entrenchment/defense (Víctor M. Mijares, 2015). Even Mijares continues his criticism that Venezuelan diplomacy is only filled with rhetoric because Chavismo's influence and actions have weakened. In addition, Mijares assessed that Maduro was unable to manage the political control system created by Chávez, the control system itself relied on resources from political control that came from a combination of military and civilian socialists, as well as most mayors and governors. Chávez's policies were much more swift and one-sided, especially with regard to the questions of the Bolivarian Revolution.

But in fact this power is not optimally managed by Maduro. Maduro instead has to negotiate every decision in order to remain able to maintain his coalition. Unlike Chávez who is able to use his power unilaterally to make decisions. Differences in background so affect the pattern of leadership between Chávez and Maduro. The charismatic figure of Chávez and comes from the military is difficult for Maduro to compete with. So deepening support for Maduro from the parties, the bureaucracy and the military is not easy.

This is evidenced by the low popularity of Maduro, resulting in only less than 25 percent popular support for him. It is undeniable that the Bolivarian Revolution 


\section{Hendra Maujana Saragih, Muhammad Fikri Matdoan}

Chavismo and Venezuelan Foreign Policy

Against the United States During 2013-2019

carried out by Chávez is connected with the revolution carried out by Fidel Castro in Cuba, Havana for Mijares has contributed what he calls an ideological and strategic "software" from Fidel Castro who finds his material expression in the "toolkit". hard" oil-based and income from Venezuela under Chávez." Maduro for Mijares is Chávez's confidant who is considered the closest to Cuba, but unfortunately Maduro displays very weak political abilities (Víctor M. Mijares, 2015). With the emergence of protests, repression, and arrests of opposition groups in 2014 have tarnished the image of the Venezuelan government in the eyes of the international community. Chávez used to build a system of alliances or coalition forces that was solid enough to convince the world public of the Bolivarian Revolution because the existing opposition only reflected foreign powers and the status quo of the previous regime, or Punto Fijo. Through Chávez's ability to consolidate political power under his control, he was able to expand his influence to an international level by cooperation or alliance. Therefore according to "Maduro's legitimacy and politicians depend on how much he is able to be consistent with the goals that Chavismo wants to achieve." To prove his commitment to Chavismo he adopted the Plan De La Patria (20132019) which was approved by the national assembly. Because Plan De La Patria defines the main objective of foreign policy as to "(contribute) to the shaping of international geopolitics for a multicentric and multipolar world. Which supports (the creation of. Translator) balance and guarantees for peace in the world." Maduro is expected to continue to rely on the connections Chavez has formed in the future.

More is not an option for Maduro to lean on the west. This is what needs to be done to harmonize with Russia in an effort to guarantee Venezuela. In 2015 cooperation between Venezuela and Russia almost touched the figure of US \$ 6.6 billion. Likewise in monetary matters, it is well known that Venezuela rejects the involvement of the IMF and the World Bank in managing the Venezuelan economy. So the Venezuelan government needs an alternative that can guarantee life for its monetary space. Venezuela's relations with China will be closely watched because Maduro desperately needs China as a guarantor of the Venezuelan economy. China also considers that cooperation with Venezuela is not a form of intervention, even though the opportunity is possible, because China only feels that it has bilateral cooperation without being followed by other 
NEGREI : Academic Journal of Law and Govenance,

Volume 1 Nomor 12021

motives. Economic ties with Venezuela that have been built since 2001 are considered to be getting stronger because China's industry desperately needs oil supplies from Venezuela to be able to compete in the economic contestation with the United States which is currently referred to as trade war, in 2016 Venezuela's $\$ 45$ billion loan to China was repaid using oil reserves Víctor M. Mijares, 2015, see tempo.com 2019). Venezuela will not directly contest in a large-scale fight because Maduro is considered also to focus on institutional powers such as ALBA because it will encourage the strengthening of Maduro's legitimacy within the country Mijares in 2015 and then predicted that the change would drag Venezuela to a narrowing of space for Venezuela, because Venezuela will not directly face the power of the United States but is represented by other political forces. As evidenced by the crisis that hit Venezuela, Maduro changed the direction of his foreign policy.

This condition may narrow Maduro's space and will make it difficult for him to express foreign policies that are directed at the United States. However, Venezuela is not without hope at all, these difficulties can still be overcome at least by appointing Venezuela as a non-permanent member of the United Nations Security Council (UNSC) in 2014. The opportunity to become a member of the UN Security Council is certainly very useful as an international foundation for Maduro to work together. can continue to maintain the course of the Bolivarian Revolution. That's why Maduro appointed Maria Gabriela Chávez, the daughter of the Chávez, as his representative on the UN Security Council.

\section{Conclusion}

Everything that is happening in Venezuela today, both the economic, political, and social crisis seems to confirm that the crisis in Venezuela is a legacy are fact and a unique political pattern. As has happened from the time of Carlos Andrés Pérez (1979) to Nicholás Maduro (2019) at this time, every regime changes with the economic crisis as its main problem. It was only during Chávez's time that Venezuela could enjoy a slight improvement in the quality of life. Chávez has paved the way for Venezuelan foreign policy by broadening the scope of the Bolivarian Revolution and introducing twenty-first century socialism. As a Chavistas, Nicholás Maduro has a very heavy responsibility to continue all the revolutionary efforts that Chávez has initiated. In foreign policy, it is indeed very difficult to find Chavistas, in the sense of the community supporting Chávez, to 


\section{Hendra Maujana Saragih, Muhammad Fikri Matdoan \\ Chavismo and Venezuelan Foreign Policy \\ Against the United States During 2013-2019}

be directly involved in the process of making and implementing foreign policies that are specifically directed at the United States, although there are institutions in the form of citizens' branches or citizens' power, whose task is to balance state power based on the mandate of the Bolivarian constitution. So that Chavismo as a social movement does not have a significant effect on Venezuela's foreign policy making during the Maduro era. It was only during Chávez's era that Chavismo could influence foreign policy and it was easy to observe because Chávez was the source of the movement's values, but the role of Chavistas in foreign policy was not that significant. Especially in foreign policies aimed at the United States, Chávez took more of a role. Likewise with Maduro, Maduro is more dominant in the effort to fight the power of the United States. 
NEGREI : Academic Journal of Law and Govenance,

Volume 1 Nomor 12021

\section{Bibliography}

Chomsky, Noam. Neo Imperialisme Amerika Serikat. Yogyakarta: Resist Book, 2008. Cipto, Bambang Ambruknya Kredibilitas Demokrasi. Yogyakarta: Pustaka Pelajar, 2019.

Gay, L. R. Eductional Research: Competencies for Analysis and Application. Fifth Edition, United States of America: Florida International University, 1996.

Gulö, W. Metodologi Penelitian. Jakarta: Grasindo, Fourth Issued, 2005.

Harnecker, Marta. Sosialisme: Pengalaman Venezuela/Amerika Latin. Resist Book: Yogyakarta, 2015.

Jackson, Robert dan Georg Sørensen. Pengantar Studi Hubungan Internasional: Teori Dan Pendekatan. Yogyakarta: Pustaka Pelajar, Fifth Edition, 2014.

Magdoff, Fred dan John Bellamy Foster. Lingkungan Hidup Dan Kapitalisme: Sebuah Pengantar. Serpong, Tangerang Selatan: Marjin Kiri, 2018.

Mas'oed, Mohtar. Negara. Kapital Dan Demokrasi. Pustaka Pelajar: Yogyakarta, edisi ke II, 2003.

Moleong, Lexy J. Metodologi Penelitian Kualitatif. Bandung: Remaja Rosdakarya, 18th Issued, 2000. Mulyanto, Dede (ed), Coen H. Pontoh, Iqra Anugrah, dan kawan-kawan, Di Balik Marx: Sosok dan Pemikiran Friederich Engels. Serpong, Tangerang Selatan: Marjin Kiri, 2015.

Newman, Michael. Sosialisme Abad 21: Jalan Alternative Atas Neoliberalisme. Yogyakarta: Resist Book, 2006.

Sitepu, P. Anthonius. Studi Hubungan Internasional. Yogyakarta: Graha Ilmu, 2011.

Hawkins, Kirk A. Venezuela's Chavismo and Populism in Comparative. Cambridge: Cambridge University Press, 2010. diunduh dari

http://www.politicaygobierno.cide.edu/index.php/pyg/article/viewFile /164/81. pada 24 Januari 2019.

Buxton, Julia. Venezuela: Evolusi Politik Bolivarianisme. Dalam Reclaiming Latin America: experiments in radical social democracy was first published in 


\section{Hendra Maujana Saragih, Muhammad Fikri Matdoan}

Chavismo and Venezuelan Foreign Policy

Against the United States During 2013-2019

2009 by Zed Books Ltd, 7 Cynthia Street, London N19 JF, UK and Room 400, 175 Fifth Avenue, New York, NY 10010, USA.

Maya, M.l. "Venezuela: The Political Crisis of Post-Chavismo.” Social Justice, 40 (4 2014): 68-8

Akbar, Hikmatul dan Luh Risma Sandiarti, Aliansi Strategis Venezuela dalam Menghadapi Globalisasi Ekonomi, Jurnal Studi Diplomasi Dan Keamanan, Third Edition Issue 2, (2011): 187-204. http://repository.upnyk.ac.id/8168/2/Hikmatul_Akbar_Sandiarti_Alia nsi_Venezuela.pdf.

Akbar, Hikmatul and Luh Risma Sandiarti, Aliansi Strategis Venezuela Dalam Menghadapi Globalisasi Ekonomi, Page 8.

Defila, Ghaby Istia Perbandingan Kebijakan Nasionalisasi Minyak Antara Carlos Andres Perez Dan Hugo Chavez, International Relations eJournal Mulawarman University, Volume 4 Issue 4, (2016): 5-6.

Dewi, Wahyu Candra Randhi Satria, StrategiKebijakan NicolasMaduro dalam Mempertahankan Stabilitas Politik di Venezuela Pasca Chavez Periode 2013-2016, diakses dari https://docplayer.info/47260852Strategi-kebijakan-nicolas-maduro-dalam-mempertahankan- stabilitaspolitik-di-venezuela-pasca-chavez-periode.html, diakses pada 3 desember 2019 pada pukul 11:32 WIB.

Firdaus, Faradilla, Strategi Perlawanan Venezuela dalam Menghadapi Tekanan Amerika Serikat melalui ALBA Tahun 2015-2017, Department of International Relations, Faculty of Social Sciences, Political Science, Universitas Airlangga.

Lestari, Bunga Ayu, Dampak Pengembangan Shale Oil Amerika Serikat Terhadap Opec (Organization Of Exporting Countries, JOM FISIP Universitas Riau, Jilid 2 Terbitan 2 - oktober (2015): 5.

M. Mijares, Víctor, Venezuela’s Post Chávez Foreign Policy, Americas Quarterly, Winter (2015): 76. 
NEGREI : Academic Journal of Law and Govenance,

Volume 1 Nomor 12021

Marthoz, Jean-Paul, "Venezuela's Foreign Policy: A Mirage Based On A Curse", NOREF: Norwegian Peacebuilding Resource Centre, November (2014): $2-5$.

https://www.files.ethz.ch/isn/186054/5ac5220191adf69475fb57f9e303479c.pd $\mathrm{f}$

Razali, Rino, Analisis Penerapan Kebijakan Ekonomi Sosialis Venezuela Pada Masa Pemerintahan Hugo Chavez Menghadapi Imperialisme Ekonomi Amerika Serikat Tahun 1998-2013, JOM FISIP, Volume 1 Issue 2 October(2014): 9.

Septian, Wahyu, Strategi Venezuela Menyepakati ALBA Dalam Menghadapi Ekspansi Perdagangan Amerika Serikat Dikawasan Amerika Latin, Hal, 4.

Wahyu, Septian, Strategi Venezuela Menyepakati ALBA Dalam Menghadapi Ekspansi Perdagangan Amerika Serikat Dikawasan Amerika Latin, Hal 6.

Andrianto, Afeb. "Kebijakan-Kebijakan Pemerintahan Hugo Chavez di Venezuela (1999- 2011)." Skripsi. Program Studi Pendidikan Sejarah Jurusan Pendidikan Sejarah Fakultas Ilmu Sosial Universitas Negeri Yogyakarta, 2012

Saputra, Mohammad Andi. "Krisis Ekonomi dan Tuntutan Demokratisasi diVenezuela." Skripsi. Department of International Relations, Faculty of Social and Political Sciences, University of Jember, 2017.

Satria A, Mirah. "Upaya Nicolas Maduro Mengatasi Kemerosotan Legitimasi Melalui Kebijakan Barrio Adentro pada Masa Krisis Venezuela." Thesis : Master of International Relations, Faculty of Social and Political Sciences, Gajah Mada University, 2018.

Ardi Priyatno Utomo, Kompas.com, posted on November 12, 2019, "Mengungsi ke Meksiko, Eks Presiden Bolivia Evo Morales Janji Kembali Lebih Kuat", accessed from https://internasional.kompas.com/read/2019/11/12/17512761/meng ungsi-ke-meksiko-eks-presiden- bolivia-evo-morales-janji-kembali, accessed on December 12, 2019.

AS Tuduh Venezuela dan Kuba Menciptakan Kerusuhan di Amerika Selatan, diposkan pada 28/11/2019, accessed from 


\section{Hendra Maujana Saragih, Muhammad Fikri Matdoan}

Chavismo and Venezuelan Foreign Policy Against the United States During 2013-2019

https://www.voaindonesia.com/a/as-tuduh-Venezuela-dan-kubamenciptakan-kerusuhan-di-amerika-selatan/5184501.html, accessed on January 7, 2020 at 15:13 PM.

Cira Pascual Marquina, Reinaldo Iturriza: Chavismo and Its Singularities, Venezuelanalysis.com, diakses dari https://Venezuelanalysis.com/analysis/13996, posted on September12, 2019, accessed on December 26, 2019.

Cnnindonesia.com Venezuela claims thwarted coup attempt to arrest 6 officers, accessed from

https://www.cnnindonesia.com/internasional/20190627091322-134406850/Venezuela-mengklaim- gagalkan-upaya-kudeta-tangkap-6perwira, accessed on Desember, 24 2019, at 17:54 PM.

Kompas.tv, "Militer Gagalkan Upaya Kudeta Terhadap Presiden Maduro", diakses dari https://www.kompas.tv/article/39501/militer-gagalkanupaya-kudeta-terhadap-presiden-Maduro, accesed on December 24, 2019.

Majalah Tempo, si penjaga api chavismo, accessed from https://majalah.tempo.co / on February 14, 2020 on 19:05 PM.

Muhaimin, Tekan Maduro, AS Tampar Kuba dan Venezuela dengan Sanksi Baru, Diposkan pada 18 April 2019 - 03:23 WIB, diakses dari https://international.sindonews.com / read/1396814/42/tekan-

Maduro-as-tampar-kuba-dan-Venezuela-dengan-sanksi-baru-1555532624, accessed on Januari 07, 2020 on 14:58 PM

Okezone, "Perekonomian Venezuela Runtuh, Warga Kembali ke "Sistem Barter" ",

https://news.okezone.com/read/2019/05/24/18/2059768/perekono mian-Venezuela-runtuh-warga- kembali-ke-sistem-barter.

Okezone.com, "PBB Kritik Sanksi AS Yang Bekukan Aset Pemerintah Venezuela", https://news.okezone.com/read/2019/08/09/18/2089939/pbb-kritiksanksi-as-yang-bekukan-semua- aset-pemerintah-Venezuela accessed on December 26, 2019 on 20:06 PM. 
NEGREI : Academic Journal of Law and Govenance,

Volume 1 Nomor 12021

State.gov, Nicolas Maduro Corruption And Chaos In Venezuela 2, accessed from https://www.state.gov/nicolas-Maduro-corruption-and-chaos-in-

Venezuela-2/, on December 19, 2019 at 19:25 PM.

State.gov, us relations with Venezuela, accessed from https://www.state.gov/us-relations-with- Venezuela/, on December 19, 2019 at 20:00 PM.

State.gov, Venezuela, accessed from https://history.state.gov/countries/Venezuela, on December 19, 2019 at 19:00 PM.

Tempo.co (editor : Budi Riza), Cina Jajaki Hubungan dengan oposisi Venezuela secara Informal, posted on Saturday, February 23, 2019 at 17:15 PM, accesed from https://dunia.tempo.co/read/1178803/cina-jajakihubungan-dengan-oposisi-Venezuela-secara- informal, accessed on January 7, 2020 at 15:29 PM.

Voaindonesia.com, Havana: Hubungan AS-Kuba dalam "Kondisi Buruk", diposkan pada 17/12/2019 accessed from https://www.voaindonesia.com/a/havana-hubungan-as-kuba-dalamkondisi- buruk-/5208799.htm 